\title{
Aplikasi Metode Bayesian Model Averaging (BMA) dengan Pendekatan Markov Chain Monte Carlo (MCMC) untuk Peramalan Curah Hujan di Stasiun Meteorologi Kota Makassar
}

\author{
Paramita*, Suwardi Annas, \& Muhammad Kasim Aidid \\ Program Studi Statistika, Fakultas Matematika dan Ilmu Pengetahuan Alam, Universitas Negeri Makassar, Indonesia
}

Keywords: Curah Hujan, Ensemble, BMA, MCMC, CRPS

\begin{abstract}
:
Curah hujan yang turun dapat mempengaruhi produksi dari beberapa jenis pekerjaan tertentu dan dapat mengganggu aktifitas manusia. Peramalan curah hujan dalam hal ini sangat penting untuk dilakukan. Metode peramalan yang sering dilakukan yaitu metode ensemble. Namun, metode ini cenderung mengalami overdispersive atau underdispersive. Maka dilakukan suatu proses kalibrasi yaitu Bayesian Model Averaging (BMA). Metode ini mampu menggeser nilai rata-rata dan variansi agar mendekati nilai observasi. Penaksiran parameter BMA dilakukan dengan pendekatan Markov Chain Monte Carlo (MCMC) yang mampu mengatasi variasi pada distribusi BMA dan memberikan hasil informasi penting mengenai bobot dan variansi. Metode ini diaplikasikan pada Curah Hujan Bulanan Kota Makassar. Hasil analisis memberikan kesimpulan bahwa metode ensemble tidak ada yang mampu yang menangkap nilai observasi sedangkan metode BMA dengan menggunakan training window 5 mampu menangkap nilai observasi curah hujan bulan Februari, Maret, Mei, Juni, Juli, dan Agustus 2018. Nilai observasi curah hujan bulan Juni yaitu $121 \mathrm{~mm}$. Hasil peramalan dari metode ensemble untuk bulan Juni yaitu 130,6 mm, sedangkan pada metode BMA diperoleh interval ramalan untuk bulan Juni yaitu $(-61,02-156,41) \mathrm{mm}$. Nilai Continous Ranked Probability Score (CRPS) yang diperoleh untuk metode ensemble yaitu 62,07 dan metode BMA yaitu 25,24. Sehingga, metode BMA lebih baik dari metode ensemble karena nilai CRPS yang dihasilkan lebih kecil, sehingga interval yang dihasilkan dari peramalan BMA lebih banyak menangkap nilai observasi.
\end{abstract}

\section{Pendahuluan}

Peramalan merupakan bagian yang penting dari proses pengambilan keputusan sebab efektif atau tidaknya suatu keputusan umumnya bergantung pada beberapa faktor yang yang tidak dapat dilihat pada waktu keputusan itu diambil (Aswi dan Sukarna, 2006). Peramalan terbagi dalam dua jenis yaitu peramalan deterministik dan peramalan probabilistik. Peramalan deterministik memberikan hasil berupa suatu titik, sehingga kurang dapat digunakan sebagai acuan dalam membuat peramalan cuaca yang sifatnya memiliki variasi yang tinggi (Prayoga dkk, 2015). Sedangkan peramalan probabilistik merupakan suatu teknik peramalan yang bergantung pada metode yang berbeda dalam menetapkan peluang suatu kejadian dan peramalan ini dapat mengetahui ketidakpastian dari peramalan yang dilakukan (Doswell dan Brooks, 2001). Maka dari itu, penelitian ini menggunakan peramalan probabilistik.

Salah satu metode pendekatan yang sering digunakan dalam peramalan probabilistik adalah metode peramalan ensemble. Metode ensemble ini sangat baik digunakan dalam memberikan informasi penting tentang hasil peramalan. Namun bentuk peramalan ensemble cenderung underdispersive atau overdispersive. Underdispersive adalah hasil dari

\footnotetext{
* Corresponding author.

E-mail address: paramitamitha102@gmail.com
} 
peramalan cenderung terpusat pada suatu titik tertentu dengan nilai varians yang relatif rendah dan sebaliknya (overdispersive). Untuk mengatasi masalah tersebut, digunakan Bayesian Model Averaging (BMA). BMA dapat memberikan kalibrasi dan ketepatan peramalan probabilistik yang lebih unggul daripada ensemble sederhana (Prayoga dkk, 2015). Kelebihan dari metode BMA yaitu dapat menggeser atau menyesuaikan nilai rata-rata dan variansi dari hasil peramalan sedemikian rupa sehingga dapat mendekati nilai observasi. Peramalan dengan metode BMA dapat dilakukan dengan pendekatan Markov Chain Monte Carlo (MCMC). Penggunaan metode BMA-MCMC juga mampu mengatasi variasi pada distribusi BMA dan dapat memberikan informasi penting mengenai perkiraan bobot dan variasi (Vrugt dkk, 2008). Peramalan dengan metode BMA dapat digunakan untuk meramalkan temperatur, tekanan udara, jumlah curah hujan, kecepatan angin, arah angin, vektor angin, dan parameter potensial yang lain (Prayoga dkk, 2015). Oleh karena itu, dalam penelitian ini akan menggunakan metode BMA-MCMC untuk meramalkan curah hujan bulanan di kota Makassar. Peramalan curah hujan merupakan hal yang sangat dibutuhkan dalam kehidupan manusia. Karena ada beberapa jenis pekerjaan tertentu, hujan yang turun dapat mempengaruhi hasil produksi. Peramalan curah hujan digunakan untuk mengetahui curah hujan yang akan turun pada suatu tempat sehingga tidak merugikan aktifitas manusia.

\section{Tinjauan Pustaka}

\subsection{Peramalan Time Series}

Deret waktu (time series) merupakan serangkaian data pengamatan yang terjadi berdasarkan indeks waktu secara berurutan dengan interval waktu tetap. Model time series yang umum digunakan yaitu model AutoRegressive Integrated Moving Average (ARIMA). Menurut Aswi dan Sukarna (2006) pemilihan model time series ARIMA dilakukan berdasarkan pendekatan Box-Jenkins, yaitu identifikasi model yang bertujuan untuk mengetahui bahwa data yang digunakan stasioner dalam rata-rata dan variansi, penaksiran parameter, Pemeriksaan diagnostik yang terbagi menjadi dua, yaitu uji kesignifikanan parameter dan uji kesesuaian model, Melakukan peramalan apabila parameter model signifikan dan asumsi residual terpenuhi.

\subsection{Metode Ensemble}

Peramalan ensemble merupakan suatu metode prediksi numerik yang digunakan untuk membangkitkan sampel dari suatu keadaan mendatang (Purnamasari, 2011). Pembentukan ensemble didasarkan pada beberapa model yang sesuai, sehingga hasil peramalannya didasarkan pada probability dencity function (pdf) bukan dari nilai peramalan tunggal (Zhu, 2005). Kelebihan dari peramalan dengan menggunakan ensemble yaitu dapat menangkap adanya unsur ketidakpastian. Namun, pada metode ini sering terjadi underdispersive atau overdispersive sehingga dibutuhkan suatu proses kalibrasi, salah satunya yaitu Bayesian Model Averaging (BMA).

\subsection{Bayesian Model Averaging (BMA)}

Metode Bayesian Model Averaging (BMA) memberikan pembaharuan terhadap pemodelan dengan tidak hanya menggunakan satu model terbaik, tetapi dengan menggunakan seluruh kemungkinan ensemble yang dapat dijadikan pertimbangan ( Raftery dkk, 2003). Menurut Vrugt dkk (2008) menyatakan bahwa metode ini tidak hanya mengacu pada satu model yang terbaik saja, namun juga mempertimbangkan model lain yang signifikan kemudian diberikan bobot sesuai dengan besar kontribusi dari masing-masing model individu terhadap kemampuan prediksi. Hasil dari metode ini lebih akurat dan handal daripada hasil yang didapatkan dengan metode kalibrasi yang lain.

Misal diberikan $f_{k}=f_{1}, f_{2}, \ldots, f_{K}$ dengan $k$ adalah prediksi ensemble yang diperoleh dari $K$ model dan $y$ adalah peramalan ensemble yang terkalibrasi, maka model prediksi BMA (distribusi posterior) untuk peramalan ensemble dapat dituliskan dalam sebuah model mixture dengan bentuk sebagai berikut (Raftery dkk, 2003; Vrugt dkk, 2008; dan Purnamasari, 2011).

$$
p\left(y \mid f_{1}, f_{2}, \ldots, f_{K}\right)=\sum_{k=1}^{K} w_{k} g_{k}\left(y \mid \bar{f}_{k}\right)
$$


Dimana $w_{k}$ menyatakan peluang posterior dari peramalan $k$ yang terbaik. $w_{k}$ memiliki nilai nonnegatif dan berjumlah satu dari keseluruhan model pada setiap anggota ensemble, dan dapat disebut sebagai bobot yang mencerminkan kontribusi model individu terhadap prediksi selama periode training. Sedangkan $g_{k}\left(y \mid \bar{f}_{k}\right)$ adalah pdf gamma yang dipengaruhi oleh jumlah peramalan ensemble $f_{k}$ melalui hubungan $\mu_{k}=b_{0}+b_{1 k} f_{k}$ and $\sigma_{k}=c_{0}+c_{1 k} f_{k}$, dimana nilai $\mu_{k}$ adalah nilai koreksi bias dari distribusi dan $\sigma_{k}$ adalah nilai standar deviasi anggota ensemble yang diperoleh dengan menggunakan regresi linear pada masing-masing anggota ensemble $K$ dan observasi. Untuk nilai $b_{0}$ dan $b_{1}$ yang diperoleh dari hasil meregresikan antara nilai peramalan ensemble dan nilai observasinya dengan menggunakan persamaan sebagai berikut (Tiro, 2010).

$$
b_{0}=\frac{\left(\sum Y_{i}\right)\left(\sum X_{i}{ }^{2}\right)-\left(\sum X_{i}\right)\left(\sum X_{i} Y_{i}\right)}{n \sum X_{i}{ }^{2}-\left(\sum X_{i}\right)^{2}}
$$

Sedangkan untuk persamaan $b_{1}$ yaitu

$$
b_{1}=\frac{n \sum X_{i} Y_{i}-\left(\sum X_{i}\right)\left(\sum Y_{i}\right)}{n \sum X_{i}^{2}-\left(\sum X_{i}\right)^{2}}
$$

Dimana $n$ adalah banyaknya data yang digunakan. $X$ adalah variabel nilai peramalan ensemble dan $Y$ adalah variabel nilai observasi. Nilai $\mu_{k}$ dan $\sigma_{k}$ dapat digunakan untuk mengestimasi parameter skala dan parameter bentuk sehingga diperoleh pdf gamma $g_{k}\left(y \mid \bar{f}_{k}\right)$ (Sloughter dkk, 2010). Setelah melakukan prediksi model dengan menggunakan BMA, maka perlu dilakukan estimasi parameter bobot dan varians dari pdf BMA. Salah satu pendekatan yang bisa digunakan untuk mengestimasi kedua parameter tersebut yaitu algorithma Markov Chain Monte Carlo (MCMC) (Vrugt dkk, 2008).

\subsection{Markov Chain Monte Carlo (MCMC)}

Simulasi MCMC digunakan sebagai pendekatan untuk mengestimasi bobot dan variasi BMA. Simulasi MCMC menggunakan jalur yang memiliki perbedaan, secara serempak untuk sampel $w_{k}, k=1, \ldots, K$ dan $\sigma^{2}$ secara khusus, didasarkan pada pembobotan yang diberikan pada fungsi likelihood. Metode simulasi MCMC yang akhir-akhir ini dikembangkan adalah DiffeRential Evolution Adaptive Metropolis (DREAM). Pada DREAM, sejumlah N rantai Markov yang berbeda dijalankan secara simultan parallel. Jika state dari rantai tunggal diberikan oleh sebuah vektor $\theta$ berdimensi $d$, dimana $\theta=w_{1}, w_{2}, \ldots, w_{K}$, maka masing-masing generasi dari $N$ dalam DREAM mendefinisikan suatu populasi $\Omega$ berukuran $N x d$. Lompatan dalam rantai $i=\{1,2, \ldots, N\}$ dibangkitkan dengan mengambil beda dari beberapa rantai lain dari $\Omega$ yang dipilih secara random:

$$
\vartheta^{i}=\theta^{i}+\gamma(\delta) \sum_{j=1}^{\vartheta} \theta^{r(j)}-\gamma(\delta) \sum_{j=1}^{\vartheta} \theta^{r(n)}+e
$$

Dimana $\delta$ merupakan jumlah pasangan yang digunakan untuk menghasilkan titik ramalan dan $r(j), r(n) \in\{1,2, \ldots, N-1\} ; r(j) \neq r(n)$. Dalam memutuskan penerimaan titik ramalan digunakan rasio metropolis. Deret hasil operasi dalam sampel MCMC dapat menghasilkan parameter robust secara efisien, karena gabungan pdf dari faktor rantai $N$ untuk $\pi\left(\theta_{1}\right) x . . x \pi\left(\theta_{N}\right)$, dengan state $\theta_{1} \ldots \theta_{N}$ dari rantai individu bersifat independen dalam berbagi bentuk setelah nilai DREAM menjadi independen (Vrugt dkk, 2008). 


\subsection{Continous Ranked Probability Score (CRPS)}

CRPS merupakan suatu ukuran untuk menilai hasil kalibrasi yang dihasilkan dengan menggunakan metode BMA, dimana suatu hasil peramalan dapat dikatakan baik jika nilai CRPS yang dihasilkan adalah nilai yang paling minimum. Pemilihan metode CRPS sebagai metode evaluasi ketepatan hasil peramalan yang dihasilkan adalah nilai peramalan terkalibrasi dalam bentuk pdf. Persamaan menghitung CRPS adalah sebagai berikut (Prayoga dkk, 2015)

$$
\text { CRPS }=\frac{1}{N} \sum_{i=1}^{N} \int_{x=-\infty}^{x=\infty}\left(F_{i}^{f}(x)-F_{i}^{0}(x)\right)^{2} d x
$$

Dimana $F_{i}^{f}(x)$ cdf dari hasil peramalan ke- $i$, sedangkan $F_{i}^{0}(x)$ dalah pengamatan sebenarnya ke- $i$ dan $N$ adalah jumlah hari dilakukannya peramalan.

\subsection{Curah Hujan}

Curah hujan dapat diartikan sebagai ketinggian air hujan yang terkumpul dalam tempat yang datar, tidak menguap, tidak meresap, dan tidak mengalir. Curah hujan $1 \mathrm{~mm}$, artinya dalam luasan satu meter persegi pada tempat yang datar tertampung air setinggi $1 \mathrm{~mm}$ atau tertampung air sebanyak 1 Liter. Menurut BMKG (2012) Kriteria intensitas hujan dibagi menjadi 4 kategori, yaitu:

a. Hujan Ringan: intensitas 5-20 mm/hari

b. Hujan Sedang: intensitas $20-50 \mathrm{~mm} / \mathrm{hari}$

c. Hujan Lebat: intensitas $50-100 \mathrm{~mm} / \mathrm{hari}$

d. Hujan Sangat Lebat: intensitas $>100 \mathrm{~mm} / \mathrm{hari}$

\section{Metode Penelitian}

\subsection{Jenis Penelitian}

Jenis penelitian yang digunakan adalah penelitian kuantitatif dengan pendekatan eksploratif dengan menggunakan metode kalibrasi Bayesian Model Averaging (BMA) untuk kalibrasi hasil peramalan.

\subsection{Sumber Data}

Data yang digunakan dalam penelitian ini merupakan data sekunder yang bersumber dari Publikasi Badan Pusat Statistik Kota Makassar pada tahun 2010 sampai dengan tahun 2018 yang merupakan hasil pengamatan Badan Meteorologi, Klimatologi, dan Geofisika (BMKG) wilayah IV, Stasiun Meteorologi Maritim Paotere Makassar. Data yang digunakan yaitu data curah hujan pada Bulan Januari 2010 - Desember 2018.

\subsection{Definisi Operasional Peubah}

Variabel penelitian yang digunakan yaitu variabel curah hujan bulanan Kota Makassar bulan Januari 2010 Desember 2018 dengan skala rasio dan waktu dalam satuan bulanan. Curah hujan adalah ketinggian air hujan yang terkumpul dalam tempat yang datar, tidak menguap, tidak meresap, dan tidak mengalir.

\subsection{Teknik Analisis Data}

Dalam penelitian ini, teknik analisis data yang dilakukan yaitu:

1. Membagi data menjadi dua bagian yaitu in-sample dan out-sample. Data in-sample terdiri dari Januari 2010 - Juli 2017. Data out-sample terdiri dari Agustus 2017 - Desember 2018.

2. Analisis deskriptif terhadap data curah hujan in-sample dan out-sample.

3. Melakukan analisis time series model ARIMA dengan menggunakan data in-sample.

4. Melakukan peramalan ensemble dari model ARIMA yang signifikan. 
5. Melakukan proses kalibrasi peramalan ensemble dengan menggunakan metode BMA.

6. Mencari nilai CRPS dari metode ensemble dan BMA.

\section{Hasil dan Pembahasan}

\subsection{Deskripsi Data Penelitian}

Data curah hujan kota Makassar yang digunakan sebanyak 108 bulan, yaitu bulan Januari 2010 sampai Desember 2018. Data curah hujan ini dibagi menjadi 2 bagian yaitu data in-sample dan out-sample. Data in-sample adalah data yang digunakan untuk training atau pemodelan yang terdiri dari 91 bulan yaitu bulan Januari 2010 - Juli 2017. Sedangkan data out-sample adalah data yang digunakan untuk testing atau kebaikan model yang terdiri dari 17 bulan yaitu bulan Agustus 2017 - Desember 2018. hasil analisis deskriptif data curah hujan kota Makassar dengan data insample.

Tabel 1 Deskriptif Data Curah Hujan In-Sample Kota Makassar

\begin{tabular}{lr}
\hline \multicolumn{1}{c}{ Statistik } & Nilai \\
\hline N & 91,00 \\
Rata-rata & 251,40 \\
Simpangan Baku & 262,10 \\
Rentang & 976,60 \\
Nilai Minimum & 0,00 \\
Nilai Maksimum & 976,60 \\
Skewness & 1,09 \\
Kurtosis & 0,29 \\
\hline
\end{tabular}

Pada Tabel 1 diketahui bahwa curah hujan kota Makassar pada bulan Januari 2010 sampai Juli 2017 memiliki ratarata 251,40 mm. Hal ini menunjukkan bahwa rata-rata curah hujan yang terjadi di kota Makassar pada tahun 2010 sampai 2017 merupakan hujan yang sangat lebat. Curah hujan tertinggi yaitu mencapai 976,60 mm dan curah hujan hujan terendah mencapai $0,00 \mathrm{~mm}$. Selisih nilai atau rentang data curah hujan tertinggi dengan terendah memiliki nilai yang tinggi yaitu 976,60, memberikan indikasi besarnya keragaman yang terjadi, hal ini dapat diketahui dari nilai simpangan baku sebesar 262.10. Nilai skewness yang benilai positif yaitu sebesar 1,09 menunjukkan bahwa pola distribusi data curah hujan tidak simetri serta kurtosis yang bernilai positif yaitu sebesar 0,29. Analisis deskriptif data curah hujan kota Makassar dengan data out-sample dapat dilihat pada Tabel 4.1.2

Tabel 2 Deskriptif Data Curah Hujan Out-Sample Kota Makassar

\begin{tabular}{lr}
\hline \multicolumn{1}{c}{ Statistik } & Nilai \\
\hline N & 17,00 \\
Rata-rata & 299,80 \\
Simpangan Baku & 342,40 \\
Rentang & 954,00 \\
Nilai Minimum & 1,00 \\
Nilai Maksimum & 955,00 \\
Skewness & 0,89 \\
Kurtosis & $-0,90$ \\
\hline
\end{tabular}

Pada Tabel 2 diketahui bahwa curah hujan kota Makassar pada bulan Agustus 2017 sampai Desember 2018 memiliki rata-rata 299,8 mm. Hal ini menunjukkan bahwa rata-rata curah hujan yang terjadi di kota Makassar pada tahun 2017 sampai 2018 merupakan hujan yang sangat lebat. Curah hujan tertinggi yaitu mencapai 955,00 mm dan curah hujan hujan terendah mencapai $1,00 \mathrm{~mm}$. 


\subsection{Analisis Time Series Model ARIMA}

\subsubsection{Plot Data Time Series}

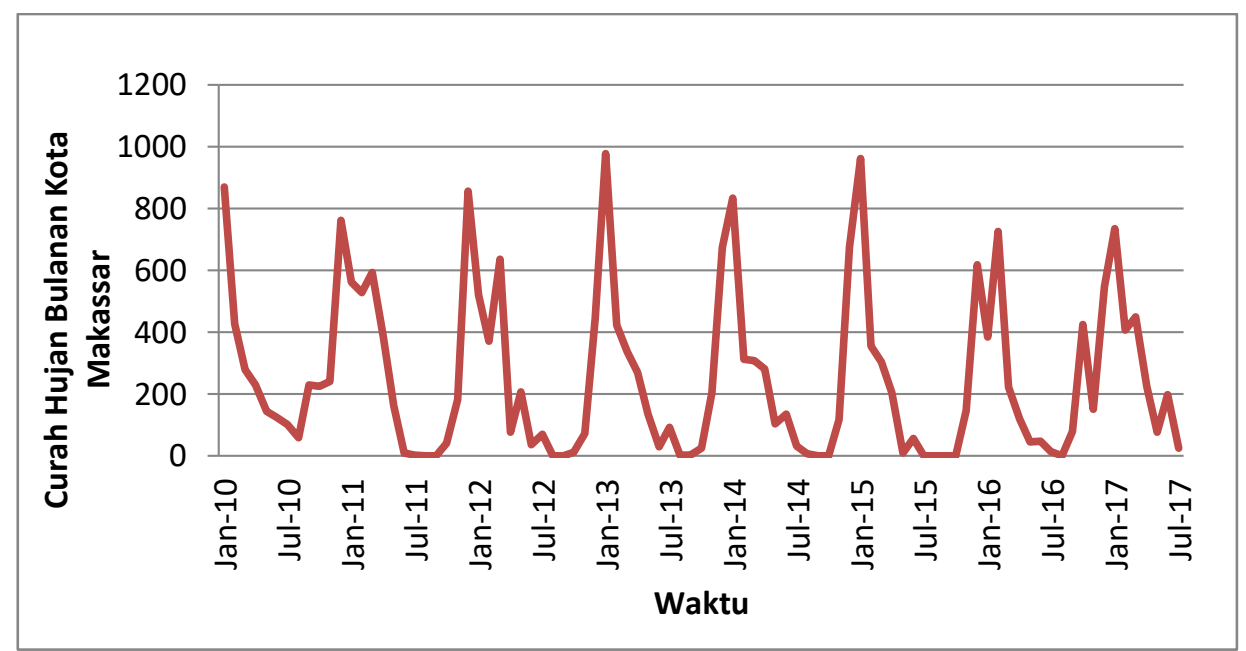

Gambar 1 Plot Time Series Data In-sample Curah Hujan Bulanan Kota Makassar

Peramalan time series model ARIMA untuk data in-sample curah hujan Kota Makassar digunakan untuk mengetahui model terbaik yang akan digunakan untuk membangkitkan data peramalan ensemble.

\subsubsection{Identifikasi Kestasioneran Data}

Langkah awal kestationeran dilakukan dengan menggunakan melihat plot ACF dan PACF seperti Gambar 2.

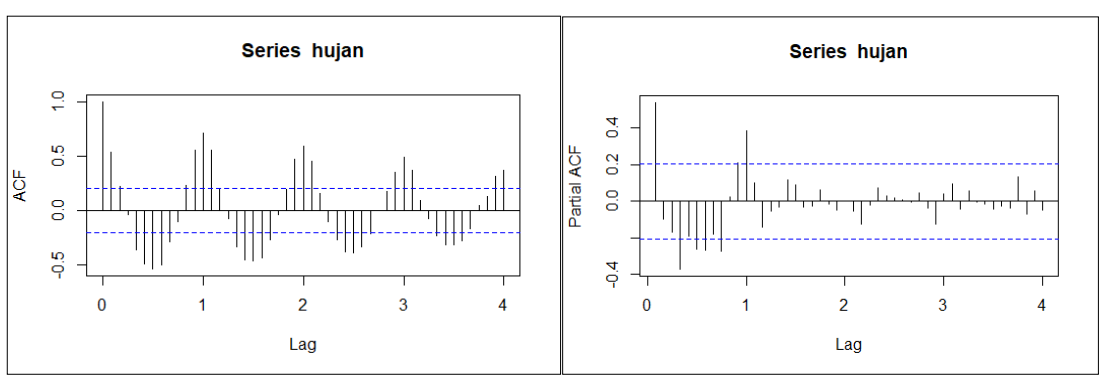

Gambar 2 Plot ACF dan PACF Data In-Sample Curah Hujan Bulanan Kota Makassar

Berdasarkan Gambar 2, plot ACF dan plot PACF memiliki pola yang turun menuju nol secara perlahan atau lambat dari lag 1. Nilai korelasi yang signifikan dan mengalami penurunan secara lambat, dapat dikatakan bahwa data belum stasioner dalam rata-rata non musiman dan rata-rata musiman 12. Maka untuk mengatasi masalah tersebut dan untuk menghilangkan kuatnya pengaruh musiman dilakukan differencing pertama non musiman $(d=1)$ dan untuk menghilangkan kuatnya pengaruh musiman dilakukan differencing pertama musiman dua belas $(D=1)$. Hasil data curah hujan setelah dilakukan differencing pertama non musiman dan musiman 12 dapat dilihat pada Gambar 3.

Berdasarkan plot pada Gambar 3 diketahui bahwa data telah stasioner dan dilihat pada hasil uji Augmented Dickey Fuller diperoleh nilai $p$-value 0,01 yang lebih kecil dari nilai $\alpha(0,05)$. Hal ini menujukkan bahwa data telah stasioner. Data tersebut dapat langsung digunakan untuk mendapatkan model ARIMA musiman yang terbaik berdasarkan plot ACF dan PACF pada Gambar 4. 


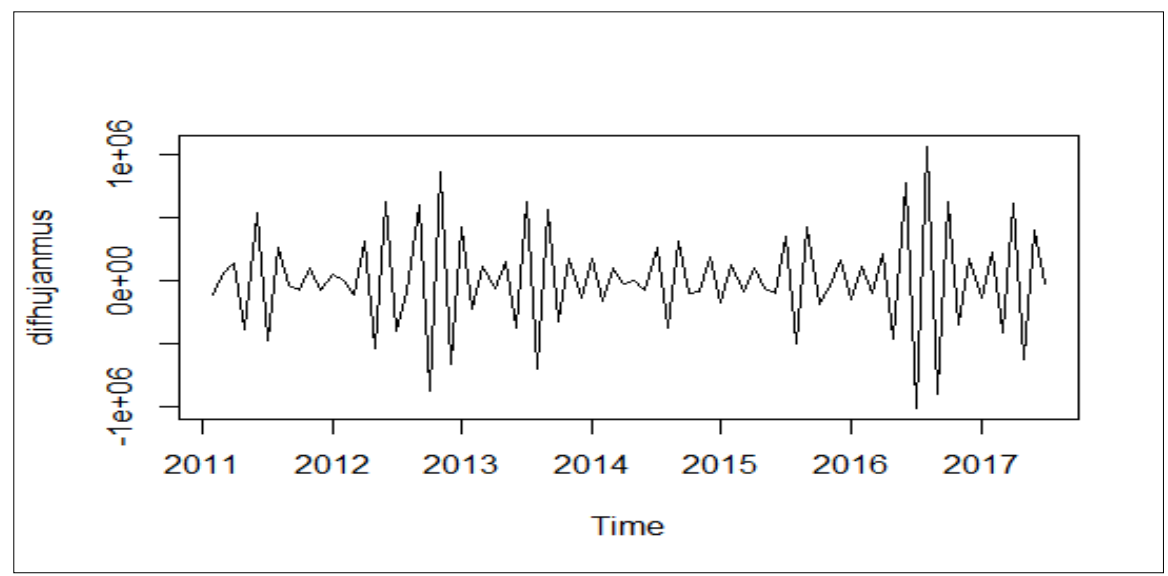

Gambar 3 Plot Time Series Data In-sample Curah Hujan Bulanan Kota Makassar Hasil Differencing Non Musiman dan Musiman 12

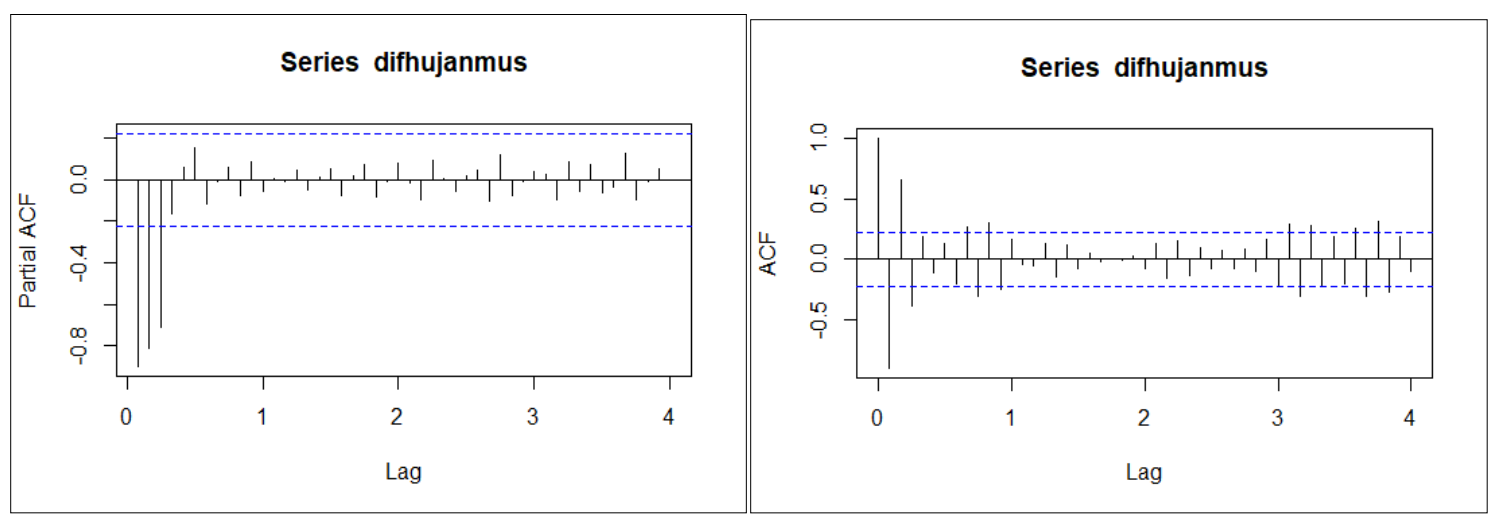

Gambar 4 Plot ACF dan PACF Data In-sample Curah Hujan Bulanan Kota Makassar Hasil Differencing Non Musiman dan Musiman 12

\subsubsection{Identifikasi Model ARIMA Musiman yang Sesuai}

Dugaan model ARIMA musiman berdasarkan analisis kestationeran data yaitu ARIMA $(1,1,1)(0,1,1)^{12}$, ARIMA $(2,1,2)(0,1,1)^{12}$, dan ARIMA $(3,1,3)(0,1,1)^{12}$. Model ARIMA yang memenuhi kesignifikanan parameter digunakan untuk membangkitkan data peramalan ensemble untuk periode-periode berikutnya. Berdasarkan Tabel 3 hanya ada satu model ARIMA yang memenuhi yaitu ARIMA $(3,1,3)(0,1,1)^{12}$. Model tersebut memenuhi kesignifikanan parameter dengan nilai $p$-value yang lebih kecil dari nilai $\alpha(0,05)$, asumsi white noise terpenuhi dengan nilai $p$-value 0,335 yang lebih besar dari nilai $\alpha(0,05)$, dan uji normalitas residual dengan nilai $p$-value $(0,095)$ yang lebih besar dari nilai $\alpha(0,05)$. Pada Tabel 4.2.3.1 model yang digunakan untuk membangkitkan data ensemble yaitu model ARIMA $(3,1,3)(0,1,1)^{12}$ karena model tersebut memenuhi kriteria kesignifikanan parameter dan kelayakan model. Secara metematis model ARIMA tersebut dituliskan seperti berikut.

$$
\begin{gathered}
\phi_{p}(B)(1-B)\left(1-B^{12}\right) \dot{Z}_{t}=\theta_{q}(B) \Theta_{Q}\left(B^{12}\right) a_{t} \\
\left(1-\phi_{1} B-\phi_{2} B^{2}-\phi_{3} B^{3}\right)(1-B)\left(1-B^{12}\right) \dot{Z}_{t}=\left(1-\theta_{1} B-\theta_{2} B^{2}-\theta_{3} B^{3}\right)\left(1-\Theta_{1} B^{12}\right) a_{t}
\end{gathered}
$$


Tabel 3 Evaluasi Model ARIMA Musiman

\begin{tabular}{|c|c|c|c|c|c|}
\hline \multirow{2}{*}{ Model } & \multicolumn{2}{|c|}{ Parameter Model } & \multirow{2}{*}{$\begin{array}{l}\text { White Noise } \\
(P \text {-Value })\end{array}$} & \multirow{2}{*}{$\begin{array}{c}\text { Residual } \\
\text { Normal } \\
(P \text {-Value })\end{array}$} & \multirow{2}{*}{ Keterangan } \\
\hline & Parameter & P-Value & & & \\
\hline \multirow{4}{*}{$\begin{array}{c}\text { ARIMA } \\
(1,1,1)(0,1,1)^{12}\end{array}$} & $\mathrm{AR}(1)$ & 0,113 & \multirow{4}{*}{0,304} & \multirow{4}{*}{0,010} & \multirow{4}{*}{$\begin{array}{c}\text { Tidak } \\
\text { Signifikan }\end{array}$} \\
\hline & MA(1) & 0,000 & & & \\
\hline & $\operatorname{SMA}(12)$ & 0,000 & & & \\
\hline & Constant & 0,099 & & & \\
\hline \multirow{6}{*}{$\begin{array}{c}\text { ARIMA } \\
(2,1,2)(0,1,1)^{12}\end{array}$} & $\mathrm{AR}(1)$ & 0,173 & \multirow{6}{*}{0,249} & \multirow{6}{*}{0,010} & \multirow{6}{*}{$\begin{array}{c}\text { Tidak } \\
\text { Signifikan }\end{array}$} \\
\hline & $\operatorname{AR}(2)$ & 0,062 & & & \\
\hline & $\mathrm{MA}(1)$ & 0,378 & & & \\
\hline & $\mathrm{MA}(2)$ & 0,359 & & & \\
\hline & $\operatorname{SMA}(12)$ & 0,000 & & & \\
\hline & Constant & 0,000 & & & \\
\hline \multirow{8}{*}{$\begin{array}{c}\text { ARIMA } \\
(3,1,3)(0,1,1)^{12}\end{array}$} & $\mathrm{AR}(1)$ & 0,000 & \multirow{8}{*}{0,335} & \multirow{8}{*}{0,095} & \multirow{8}{*}{ Signifikan } \\
\hline & $\mathrm{AR}(2)$ & 0,000 & & & \\
\hline & $\operatorname{AR}(3)$ & 0,015 & & & \\
\hline & MA(1) & 0,000 & & & \\
\hline & MA(2) & 0,000 & & & \\
\hline & $\operatorname{MA}(3)$ & 0,000 & & & \\
\hline & $\operatorname{SMA}(12)$ & 0,000 & & & \\
\hline & Constant & 0,000 & & & \\
\hline
\end{tabular}

\subsection{Peramalan Ensemble Data Curah Hujan Kota Makassar}

Peramalan ensemble dalam penelitian ini dilakukan dengan dengan memperbarui model dari bulan ke bulan, bukan melakukan peramalan dalam banyak periode. Peramalan untuk model yang sesuai dilakukan dengan menggunakan satu Lead time, artinya peramalan untuk satu tahap atau bulan ke depan (Lead ke-1).

Dengan menggunakan data in-sample bulan Januari 2010 sampai Juli 2017, maka peramalan pertama yaitu bulan Agustus 2017. Dengan memperbarui data in-sample yaitu mengurangi satu data terlama dan menambahkan satu data terbaru, sehingga menjadi Februari 2010 sampai Agustus 2017, maka akan diperoleh data peramalan untuk September 2017. Pembaruan data ini dilakukan secara terus-menerus sampai bulan Desember 2018.

\subsection{Kalibrasi Data Peramalan Curah Hujan Kota Makassar Menggunakan Bayesian Model Averaging (BMA)}

\subsubsection{Model Prediksi Bayesian Averaging Model (BMA)}

Dalam proses kalibrasi ini digunakan nilai training window $(m)$ yaitu 5. Penggunaan nilai $m$ yang berbeda akan memberikan hasil peramalan yang berbeda pula walaupun dengan waktu yang sama. Tahap selanjutnya yang dilakukan setelah menentukan nilai $m$ yaitu adalah mencari nilai $b_{0}, b_{1}, \sigma^{2}$, dan nilai bobot. Nilai $b_{0}$ dan $b_{1}$ digunakan untuk mencari nilai koreksi bias dari peramalan ensemble untuk menggeser nilai rata-rata agar dapat mendekati nilai observasi. Nilai $b_{0}$ dan $b_{1}$ diperoleh dengan cara meregresikan data hasil peramalan ensemble terhadap data observasi dengan jumlah data yang digunakan sebanyak $m$. Untuk kalibrasi data peramalan Juni 2018 dengan nilai $m=5$, maka data yang digunakan yaitu data bulan Januari 2018 sampai Mei 2018. Dari proses regresi yang dilakukan maka diperoleh nilai $b_{0}$ dan $b_{1}$.

Nilai koreksi bias yang diperoleh untuk kalibrasi data peramalan bulan Juni 2018 menggunakan data hasil peramalan ensemble yaitu sebagai berikut:

$$
\begin{aligned}
& \mu_{k}=b_{0}+b_{1} f_{k} \\
& \mu_{k}=-1,504+1,14(130,60) \\
& \mu_{k}=147,38
\end{aligned}
$$




$$
\begin{array}{ll}
b_{0}=\frac{\left(\sum Y_{i}\right)\left(\sum X_{i}^{2}\right)-\left(\sum X_{i}\right)\left(\sum X_{i} Y_{i}\right)}{n \sum X_{i}^{2}-\left(\sum X_{i}\right)^{2}} & b_{1}=\frac{n \sum X_{i} Y_{i}-\left(\sum X_{i}\right)\left(\sum Y_{i}\right)}{n \sum X_{i}^{2}-\left(\sum X_{i}\right)^{2}} \\
b_{0}=\frac{(2.274)(1.098 .741,04)-(2.105,14)(1.255 .165,44)}{91(1.098 .741,04)-(2.105,14)^{2}} & b_{1}=\frac{91(1.255 .165,44)-(2.105,14)(2.274)}{91(1.098 .741,04)-(2.105,14)^{2}} \\
b_{0}=\frac{(2.498 .537 .120)-(2.642 .298 .974)}{(99.985 .434,4)-(4.431 .614,42)} & b_{1}=\frac{114.220 .055-4.787 .088,36}{(99.985 .434,4)-(4.431 .614,42)} \\
b_{0}=\frac{-143.761 .855}{95.553 .820} & b_{1}=\frac{109.432 .967}{95.553 .820} \\
b_{0}=-1,504 & b_{1}=1,14
\end{array}
$$

Nilai estimasi varian dan bobot diperoleh dengan menggunakan p endekatan BMA. Dari pendekatan tersebut diperoleh nilai varian dengan nilai $m=5$ yaitu $\sigma_{k}=47,47$ dan nilai bobot yaitu $w_{1}=1$. Semakin besar nilai bobot dari model, maka semakin tinggi tingkat kontribusi peramalan ensemble terhadap hasil peramalan terkalibrasi. Selain itu, diperoleh nilai $\alpha_{1}=9,64$ dan $\beta_{1}=15,29$. Maka dari itu diperoleh model prediksi BMA untuk peramalan ensemble sebagai berikut.

$$
\begin{aligned}
p\left(y \mid f_{1}\right) & =w_{1} g_{1}\left(y \mid f_{1}\right) \\
& =w_{1} g_{1}\left(\alpha_{1}, \beta_{1}\right) \\
& =1 g_{1}((9,64),(15,29))
\end{aligned}
$$

\subsubsection{Peramalan Curah Hujan Bulanan Kota Makassar dengan Metode BMA}

Peramalan curah hujan dilakukan dengan menggunakan training window $(m)$ yaitu 5 . Peramalan dengan $m=5$ berarti dalam melakukan kalibrasi peramalan data yang digunakan yaitu data 5 bulan sebelum bulan peramalan. Peramalan untuk bulan Juni 2018 dengan $m=5$, berarti data yang digunakan untuk melakukan kalibrasi peramalan yaitu bulan Januari - Mei 2018. Penggunaan nilai $m$ yang berbeda-beda dapat mempengaruhi hasil peramalan.
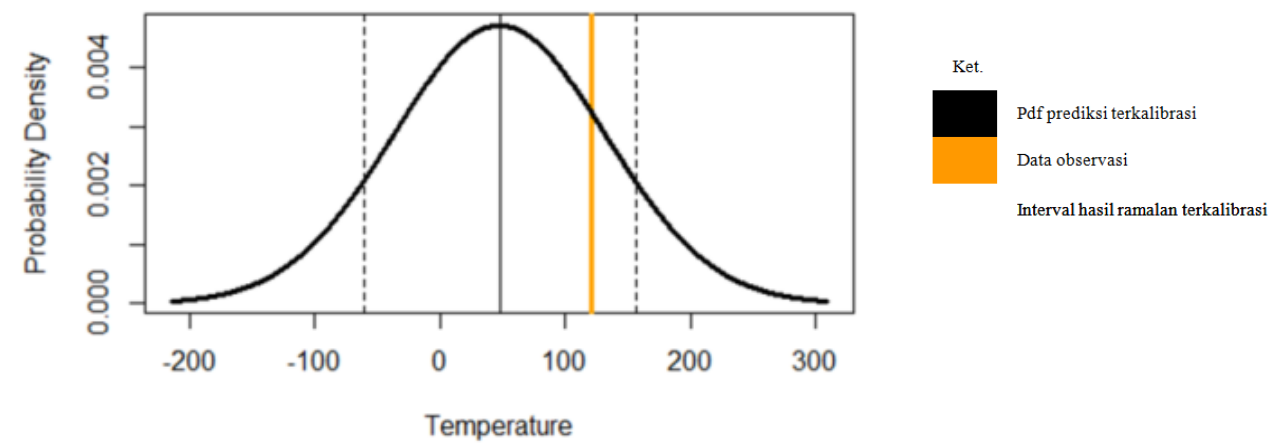

Gambar 5 Pdf Curah Hujan Bulan Juni 2018 dengan Metode BMA (Lead 1), dengan menggunakan $m=5$

Pada Gambar 5 menunjukkan hasil peramalan untuk bulan Agustus dengan nilai $m=5$ mampu menangkap nilai observasi curah hujan yaitu $1 \mathrm{~mm}$ karena nilai observasi tersebut masuk ke dalam nilai interval peramalan terkalibrasi yang dihasilkan yaitu $(-61,02-156,41) \mathrm{mm}$. 
Tabel 4 Parameter Distribusi untuk Juni 2018 Lead ke-1

\begin{tabular}{cccc}
\hline$m$ & Bobot $(w)$ & $\mu$ Kalibrasi & $\sigma^{2}$ Kalibrasi \\
\hline 5 & 1 & 147,39 & 12,14 \\
\hline
\end{tabular}

Pada Gambar 6 disajikan hasil peramalan terkalibrasi untuk periode lainnya dengan menggunakan metode BMA. Peramalan curah hujan pada bulan Februari, Maret, dan Mei 2018 dengan menggunakan metode BMA seperti pada Gambar 6 dapat menangkap nilai observasi. Dimana nilai observasi masuk atau berada pada nilai interval batas atas dan bawah ramalan terkalibrasi. Sedangkan peramalan pada bulan April 2018 nilai interval peramalan tidak mampu menangkap nilai observasi karena nilai observasi berada diluar nilai interval batas atas dan bawah hasil ramalan yang telah dikalibrasi dengan menggunakan metode BMA .

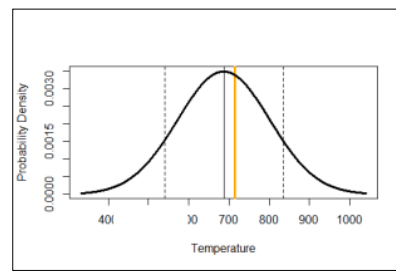

Februari 2018

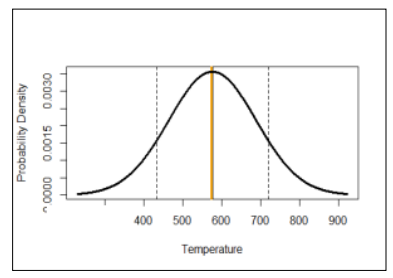

Maret 2018

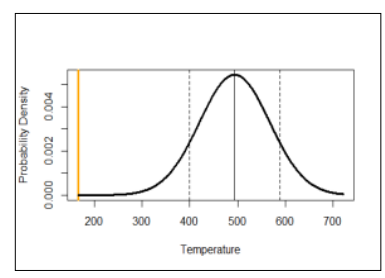

April 2018

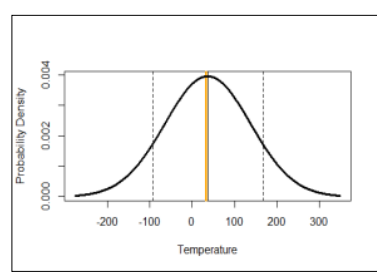

Mei 2018

Ket.

Pdf prediksi terkalibrasi

Data observasi

Interval hasil ramalan terkalibrasi

Gambar 6 Pdf Curah Hujan dengan Metode BMA untuk Beberapa Bulan Lainnya (Lead ke-1)

Hasil kalibrasi peramalan ensemble curah hujan kota Makassar tahun 2018 dengan metode BMA dapat dilihat pada Gambar 7.

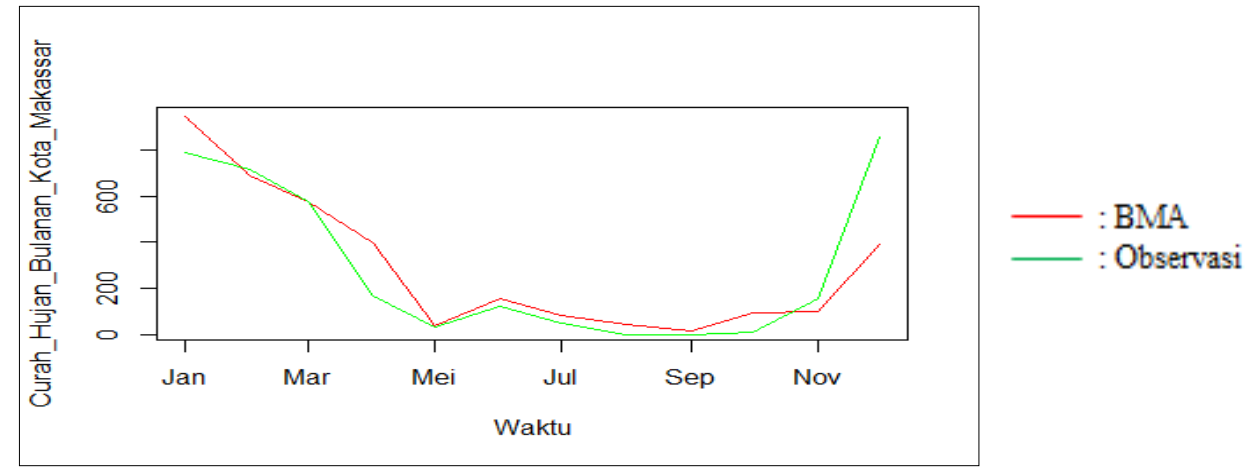

Gambar 7 Grafik Curah Hujan Hasil Peramalan BMA dengan Nilai Obsevasi

Dari Gambar 7 dapat dilihat bahwa pola data hasil ramalan terkalibrasi mengikuti kenaikan atau penurunan dari pola data observasi. Walaupun ada beberapa periode waktu hasil ramalan terkalibrasi tidak dekat dengan nilai observasinya seperti bulan Januari, April, Oktober, dan Desember 2018. 


\subsection{Evaluasi Kinerja Peramalan Ensemble dengan BMA}

Evaluasi hasil peramalan untuk masing-masing training window $(m)$ untuk lead 1 yaitu dengan menggunakan nilai Continous Ranked Probability Score (CRPS), dengan prosedur dasar yaitu dengan membandingkan distribusi hasil ramalan dengan pengamatan, yang keduanya dipresentasikan sebagai fungsi distribusi kumulatif.

Tabel 5 Evaluasi Hasil Peramalan

\begin{tabular}{ccc}
\hline Lead & Peramalan & CRPS $(m=5)$ \\
\hline \multirow{2}{*}{1} & Ensemble & 62,072 \\
& BMA Calibrate & 25,241 \\
\hline
\end{tabular}

Berdasarkan Tabel 5 dapat diketahui bahwa hasil peramalan dengan menggunakan metode kalibrasi BMA lebih baik daripada metode ensemble. Hal ini dapat dilihat dari nilai CRPS kalibrasi BMA yang dihasilkan lebih kecil dari metode ensemble.

\section{Kesimpulan}

Berdasarkan hasil analisis dan pembahasan dari penelitian ini, maka dapat diambil kesimpulan sebagai berikut..

Model ARIMA yang memenuhi kriteria kesignifikanan yaitu:

1. Model ARIMA yang memenuhi kriteria kesignifikanan yaitu ARIMA $(3,1,3)(0,1,1) 12$.

2. Model prediksi curah hujan bulanan kota Makassar dengan metode BMA yaitu:

$$
p\left(y \mid f_{1}\right)=w_{1} g_{1}\left(y \mid f_{1}\right)
$$

3. hasil kalibrasi peramalan yang dihasilkan dengan menggunakan $m=5$ optimum dalam menangkap nilai observasi. Peramalan ensemble terkalibrasi dengan BMA menangkap nilai observasi dengan $m=5$ untuk bulan Februari, Maret, Mei, Juni, Juli, dan Agsutus 2018, dimana nilai observasi masuk dalam interval peramalan. Sedangkan untuk bulan Januari, April, September, Oktober, November, dan Desember 2018, nilai observasi tidak masuk ke dalam interval peramalan.

\section{References}

Aswi, \& Sukarna. (2006). Analisis Deret Waktu. Makassar: Andira Publisher.

BMKG. (2012). Analisis Hujan April 2012 dan Prakiraan Hujan Juni, Juli, dan Agustus 2012 Sulawesi Selatan. Maros: Badan Meteorologi, Klimatologi, dan Geofisika.

Doswell, C. A., \& Brooks, H. E. (2001). Normalized Damage from Major Tornadoes in the United State: 1890-1999. Weather and Forecasting, 168-176.

Prayoga, G. S., Kuswanto, H., \& Irhamah. (2015). Aplikasi Metode Bayesian Model Averaging Dengan Pendekatan Markov Chain Monte Carlo (MCMC) Untuk Peramalan Curah Hujan Bulanan Di Stasiun Meteorologi Sukowono Jember.

Purnamasari, R. (2011). Penggunaan Metode Bayesian Model Averaging (BMA) Dengan Pendekatan Markov Chain Monte Carlo (MCMC) Untuk Peramalan Kecepatan Angin Rata-rata Harian Stasiun Meteorologi Juanda.

Raftery, A. E., Balabdaoui, F., Gneiting, T., \& Polakowski, M. (2003). Using Bayesian Model Averaging to Calibrate Forecast Ensemble.

Sloughter, J. M., Gneiting, T., \& Raftery, A. E. (2010). Probabalistic Wind Speed Forecasting Using Ensembles and Bayesian Model Averaging. Journal of the American Statistical Association, 25-35.

Tiro, M. A. (2010). Analisis Korelasi dan Regresi. Makassar: Andira Publisher.

Vrugt, J. A., Diks, C. G., \& Clark, M. P. (2008). Ensemble Bayesian Model Averaging Using Markov Chain Monte Carlo Sampling. Environ Fluid Mech.

Zhu, Y. (2005). Ensemble Forecast: A New Approach to Uncertainty and Predictability. Advances In Atmospheric Sciences, 781-788. 